\title{
THE ROLE OF TOURIST SERVICES IN THE SUSTAINABLE DEVELOPMENT OF ARAD AND TIMIS GOUNTIES
}

\section{Olimpia-Neliana TUDUR ${ }^{a *}$, Daiana-Cerasela VINICZKI ${ }^{\mathbf{b}}$, Laura Mariana CISMAȘc}

\author{
a), b), c) West University of Timişoara, Faculty of Economics and Business \\ Administration, Timişoara, Romania
}

Please cite this article as:

Tudur, O.N., Viniczki, D.C. and Cismaş, L.M., 2019. The role of tourist services in the sustainable development of Arad and Timiş counties. Review of Economic Studies and Research Virgil Madgearu, 12(2), pp.155-174.

doi: 10.24193/RVM.2019.12.46.
Article History:

Received: 10 October 2019 Accepted: 15 November 2019

\begin{abstract}
Due to the increased economic and social dynamics and also the increase of the urbanization degree, the tourism has become an engine of sustainable development and growth and thus a more detailed analysis is imposed. The paper aims to analyze and highlight, through the perspective of general and specific component elements (elements of differentiation of the tourist offer, natural, cultural - historical values, statisticaleconomic indicators of the activity in the tourism sector) the potential that tourism has in the sustainable development of Timiș and Arad counties in the West Region. In order to achieve this approach, the development strategies of the two counties are analyzed and specific indicators of tourism activity are compared. The data are obtained from the NIS and from the financial statements of the economic operators in the tourism sector. This potential study can influence the regional development policies, in the elaboration of joint projects and common strategies (regional, economic and social) for the realization of a cultural and tourist pole on the Timişoara - Arad axis.
\end{abstract}

Key words: tourism; sustainable development; strategy; number of tourists JEL Classification: $L 80 ; Z_{32}$

(C) 2019 Alma Mater Publishing House. All rights reserved.

* Corresponding author. E-mail address: olimpia.popa2017@gmail.com. 
Review of Economic Studies and Research Virgil Madgearu, 2019, 12(2)

\section{References:}

1. Anghelache, C., 2017. Starea economică la un deceniu de la aderare. București: Economica.

2. Barna, R. C., 2007. Dezvoltare regională în Europa. Cluj-Napoca: Fundația pentru Studii Europene.

3. Development strategy of Arad County. [online] Available at: http:// www.cjarad.ro/ [Accessed September 2019].

4. Development strategy of Timis County. [online] Available at: http:// www.cjtimis.ro/ [Accessed September 2019].

5. Institutul Național de Statistică, 2019. Statistică teritorială - Repere economice și sociale regionale.

6. Law no.315/2014 regarding regional development in Romania, M.O. 577/2014. [online] Available at: https://www.adrnordest.ro/ [Accessed August 2019].

7. Law no.170/2016 regarding tax specific for certain activities. [online] Available at: https://www.anaf.ro [Accessed August 2019].

8. Magazine of the Institute of the Regions of Europe no. 52/2019, Sustainable tourism to increase regional development. [online] Available at: https://ec.europa.eu/ [Accessed September 2019].

9. Ministery of Finance, 2019. [online] Available at: http://www.mfinante. gov.ro/pagina.html?pagina=acasa [Accessed September 2019].

10. National Institute of Statistics, 2019. [online] Available at: http:// www.insse.ro/cms/ro [Accessed August 2019].

11. Stanciulescu, G., 2004. Managementul turismului durabil în centrele urbane. București: Economica.

12. Țigu, G., 2008. Diferenţe culturale, etică şi comportament turistic. București: Academia de Studii Economice.

13. Touristic strategy of Arad County. [online] Available at: http://www. cjarad.ro/ [Accessed September 2019]. 